\title{
Abundance and composition of Rotifera in an abandoned meander lake (Lago Amapá) in Rio Branco, Acre, Brazil
}

\author{
Erlei Cassiano Keppeler ${ }^{1} \&$ Elsa Rodrigues Hardy ${ }^{2}$ \\ 1 Programa de Pós-Graduação em Aqüicultura, Centro de Aqüicultura, Universidade Estadual Paulista. Rodovia Carlos \\ Tonanni, 14870-000 Jaboticabal, São Paulo. E-mail: erlei@caunesp.unesp.br \\ ${ }^{2}$ Laboratório de Zooplancton, Instituto Nacional de Pesquisas da Amazônia. Avenida André Araújo, 69060-001 Manaus, \\ Amazonas, Brasil.
}

\begin{abstract}
Abundance and composition of Rotifera in an abandoned meander lake (Lago Amapá) in Rio Branco, Acre, Amazonia, Brazil. The rotifer community in Lago Amapá (abandoned meander lake of the Rio Acre floodplain) was investigated with respect to seasonal changes. Sampling was performed at three collection stations, generally weekly, during the dry season between May 8,1997 and October 31,1997, and during the rainy season between January 2,1998 and February 24,1998. The density and composition of rotifer species (48 taxons of rotifers) were determined, and their diversity and abundance were observed to be greater, respectively, at high-water and low-water. Anova was performed, by means of the $\mathrm{F}$ test, to test for seasonal differences in environmental variables and rotifers, showing that there was a highly statistically significant difference for $\mathrm{pH}$ and transparency $(\mathrm{p}<0.01)$. Pearson's correlation was used to show that rotifer numbers during the low-water phase correlated negatively with electrical conductivity $(r=-0.8824, p<0.05)$ and during the high-water phase correlated negatively with depth $(r=-0.7513, p<0.05)$. Seasonal changes, caused by an increase in water levels and the low diversification of niches, influenced the composition and abundance of the animal group studied. KEY WORDS. Floodplain, high water phase, low water phase, Rotifera community.
\end{abstract}

RESUMO. A comunidade de rotíferos do Lago Amapá (meandro abandonado da planície de inundação do Rio Acre) foi investigada sazonalmente. As amostragens foram realizadas semanalmente em três estações de coletas, em dois períodos: estação seca entre 08/V/1997 e 31/X/1997 e estação chuvosa, entre 02/I/1998 e 24/II/1998. A densidade e composição de rotíferos (48 táxons de rotíferos) foram determinadas. A diversidade e abundância foram caracterizadas por serem maiores, respectivamente, nas águas altas e águas baixas. Anova e teste $F$ foram usados, visando observar diferenças sazonais nas variáveis ambientais e rotíferos. Transparência e pH foram estatisticamente altamente significativos $(\mathrm{p}<0,01)$. As análises de correlações de Pearson revelaram que a condutividade elétrica foi negativamente correlacionada com a densidade de rotíferos $(r=-0,8824 ; p<0,05)$, na fase de águas baixas, bem como, profundidade, na fase de águas altas $(r=-0,7513 ; p<0,05)$. Mudanças sazonais, causadas pelas flutuações do nível da água, e baixa diversificação dos nichos influenciaram a composição e abundância do grupo estudado.

PALAVRAS CHAVE. Planície de inundação, fase de águas altas, fase de águas baixas, comunidade de Rotifera.

For tropical rivers with broad floodplains areas, the flood pulse is a key factor that initiates and controls the the productivity of the energy flow of these systems. Floodplains of tropical rivers differ from the river continuum where communities along the river are distributed so as to harmonize with their feeding habitats to utilize the transported material. The production of biomass and the cycling of nutrients occurs mainly in the lake area of floodplains.

The periodicity of the hydrological cycle in floodplains influences (in a positive manner) the aquatic productivity and ecological processes, as a result of changes in the areas along floodplains. Therefore, unlike the behavior predicted by the river continuum concept, in which communities are found organized along the longitudinal axis so as to maximize the transport of materials and energy from a high to low gradient, flooding events cause large changes in all of the hydrographic basin of rivers with floodplains (JUNK et al. 1989). These changes in turn influence communities such as the zooplankton, which according to Wetzel \& LiKens (1991) include major herbivores as well as important predators in aquatic ecosystems. There-

Revista Brasileira de Zoologia 21 (2): 233-241, junho 2004 
fore, to understand lake metabolism is it necessary to evaluate the biomass and the role of zooplankton in the ecosystem.

The ideal niche is defined by the tolerance levels of an organism while the observed niche is that subset of tolerable conditions actually occupied by the organism. Extreme abiotic or biotic stress can cause local extirpation of a population - the species becomes rare or even disappears from a place where it once occurred. Predators or competitors may prevent the species from effectively colonizing a habitat where abiotic conditions might otherwise allow it to survive and flourish. The order of possible answers leads to greater insight into the importance of abiotic and biotic constraints. The boundaries of possibility are defined first by tolerances, then by minimum growth and finally by successful reproduction (Kitchell 1998). Thus, hydrological connectivity influences biodiversity (АмоRos 2001).

Rotifers are very important freshwater plankton and they cover the ecologic niche of the the small filter feeders. The length of their life cycle is two weeks or less (Margalef 1983), so their study should involve samplings over a short period of time.

The ecological and taxonomic knowledge of zooplankton in continental waters is important for understanding the functioning of the aquatic ecosystem. Zooplankton in tropical regions present a diversity of species of little known distribution in lakes, mainly those from abandoned meanders. Ecosystems of this nature harbor species that they possess since ample distribution until endemic, in accordance with the extent of ecological niches propitiated by environmental conditions influenced by hydrographic basins. Rotifers are organisms that have asexual and sexual phases, representing one of the main plankton components in continental water communities. This group shows a typical geographic distribution in basins, influenced by its opportunistic form of occupation. This unique manner of occupying diverse niches of continental water ecosystems is influenced by the interaction of physical, chemical and biological parameters. These factors determine the complexity that results in the presence of different species and zooplankton groups, verified from studies of community structure.

One of the continental water systems commonly found in South America, characterized by marked seasonal changes caused by fluctuations of the water level, are the floodplains. They have been studied in Brazil, especially with regard to the composition and ecology of zooplankton: GreEN (1972) in the Pantanal Matogrossense, Lansac-TôHa et al. (1992, 1993), BONECKER et al. (1994, 1996), and BONECKER \& LANSAC-TôHA (1996). The zooplanktonic communities that inhabit different environments present in floodplains, show a standard composition and abundance, depending on the physical, chemical and biological conditions of the environment. Several studies of community structure in the Amazonian basin have examined these aspects, most noteworthy being: Carvalho (1983), Koste \& Robertson (1983), Hardy et al. (1984), Robertson \& Hardy (1984), Santos-Silva et al. (1989), Bozelli (1992, 1994), and WAICHMAN et al. (2002).
There have been few studies of zooplankton in lakes of abandoned meanders, common in the state of Acre (SENDACZ \& Melo-Costa 1991, Keppeler \& Hardy 2002). Therefore, the aims of the present work were (I) to determine the difference in the abundance and composition of Rotifera, in the major phases of the hydrologic cycle and (II) to correlate some physical, chemical and biological parameters with this composition.

\section{MATERIAL AND METHODS}

Lago Amapá is a lake belonging to the hydrographic basin of the Rio Acre, to which it is permanently linked, and is thus considered a whitewater lake according to Sioli (1968). Lago Amapá is situated in the municipality of Rio Branco with the geographic coordinates $10^{\circ} 02^{\prime} 36^{\prime \prime} \mathrm{S}$ and $67^{\circ} 50^{\prime} 24^{\prime \prime} \mathrm{W}$ (see figure 1 in KePPELER \& HARDY 2004). The lakes are surrounded by forest, which is inundated during high water, and as a consequence, there is a great input of organic matter from the forest into the lake.

According to Salati et al. (1978), the hydrologic complex of the Amazon basin, is formed by thousands of small rivers and has probably been in dynamic equilibrium, together with the exuberant forest, for millennia. The lakes studied are situated south of the equator, beyond parallel $65^{\circ} \mathrm{W}$, and receive a minimum amount of precipitation in June/July. However, whitewater streams that are in Brazilian Amazonia are very evident in the State of Acre in South Western Amazonia (SiOLI 1984).

The data on the biotic and abiotic parameters were collected at the lake generally at weekly intervals (except in October), during two periods comprising the low-water phase (dry season) between May 8, 1997 and October 30, 1997 and the high-water phase (rainy season) between January 2, 1998 and February 24, 1998. Three stations were selected: station I - a region located close to a channel that connects Lago Amapá with the Rio Acre; station II - an approximately central region of the lake; and station III; the terminal region of the lake.

To carry out a quantitative analysis of the zooplankton, the organisms were collected with a Van Dorn sampling bottle, using a conical net ( $55 \mu \mathrm{m}$ mesh) to filter 5 liters of water at different depths. The samples were preserved in a solution of $4 \%$ formaldehyde. The samplings were counted in SedgwickRafter chambers (1mL) according to АРнA (1992).

The determination of the physical, chemical and biological parameters, that is, water temperature $\left({ }^{\circ} \mathrm{C}\right)$, transparency and depth of the water column (m), electrical conductivity $\left(\mu \mathrm{S} . \mathrm{cm}^{-1}\right)$, and dissolved oxygen $\left(\mathrm{mg} . \mathrm{L}^{-1}\right)$, was according to Golterman et al. (1978), and included a modification of the assay for dissolved oxygen using sodium azide (Golterman et al. 1969).

Data were standardized (except $\mathrm{pH}$ ) by logarithmic transformation $(\log )$. The degree of significance of all values for the studied of Rotifera and environmental variables among low water period and high water period was calculated with Analy- 
sis of Variance (ANOVA). Assumptions for ANOVA were verified. The tukey Test was used for means comparison using SAS system (vs. 5, SAS 1998). The degree of significance of all values for the studied variables among Rotifera and abiotic variables was established by Pearson's coefficient of variation. Simple Linear Regression Analysis was used.

\section{RESULTS}

Environmental and biological variables were averaged for the top and middle layers, where zooplankton are generally concentrated. The means and variations are listed in table I. The composition of Rotifera included 48 taxons, of which 20 represented new registers for the floodplain of the Rio Acre (Tab. II).

Some species of Rotifera have been showen to be common. Included in collections during the low-water phase period were the following: Asplanchna sieboldi (Leydig, 1854); Brachionus caudatus Barrois \& Daday, 1884; Brachionus falcatus Zacharias, 1898; Epiphanes macrourus (Barrois \& Daday, 1894), Filinia opoliensis (Zacharias, 1898); Keratella cochlearis Gosse, 1851, and Polyarthra vulgaris Carlin, 1943. In the high-water phase, the species that predominated were Brachionus calicyflorus Pallas, 1766, Brachionus calicyflorus anuraeformis (Brehm, 1909), Filinia terminalis Plate, 1886, Keratella cochlearis hispida Lauterborn, 1900, Thrichocerca similis Plate, 1886 and Polyarthra vulgaris Carlin, 1943. Numerical density and number of Rotifera of the samples are shown in figure 1 for the three collection stations.

The rotifers showed a higher abundance in the low-water phase, especially the following species: Asplanchna brightwelli Gosse, 1850; Asplanchna sieboldi (Leydig, 1854); Brachionus calicyflorus anuraeformis, Filinia longiseta (Ehrenberg, 1834); Filinia terminalis (Ehrenberg, 1834), Filinia opoliensis (Zacharias, 1898), Keratella cochlearis Plate, 1886, and Keratella cochlearis hispida Lauterborn, 1900 (Tab. III).

Figures 2 and 3 show the Pearson correlations that were significant $(\mathrm{p}<0.05)$ between the environmental variables and density of the rotifers. Both correlations were negative. There was a correlation with electrical conductivity $(r=-0.8824$; $\mathrm{p}<0.05$ ) in the low-water phase, while this group showed a correlation with depth $(r=-0.7513 ; \mathrm{p}<0.05)$ in the high-water phase. Therefore, rotifer abundance was influenced by limnological factors.

Variance analysis and comparison of means of the rotifer and environmental variables in the low-water phase/1997 and water-high phase/1998 are in table IV.

\section{DISCUSSION}

Habitat selection is one of the most poorly understood ecological processes. The question is the following: What elements of the habitat do animals recognize as relevant? We define a habitat as any part of the biosphere where a particular

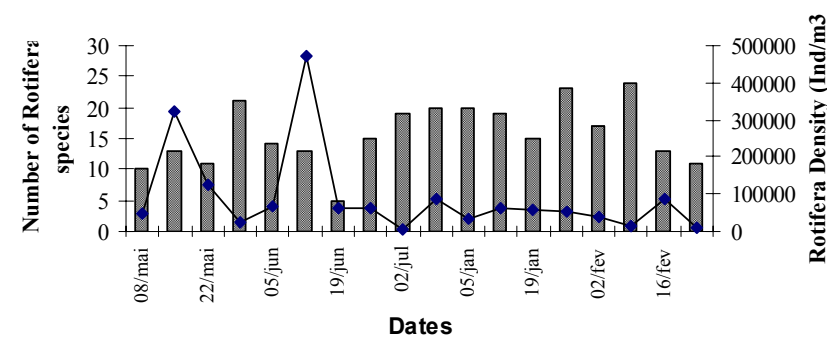

Rotifera number species $\longrightarrow$ Density Rotifera

Figure 1. Numerical density and number of Rotifera, in Amapá Lago, during the low-water phase of 1997 and high-water phase of 1998.
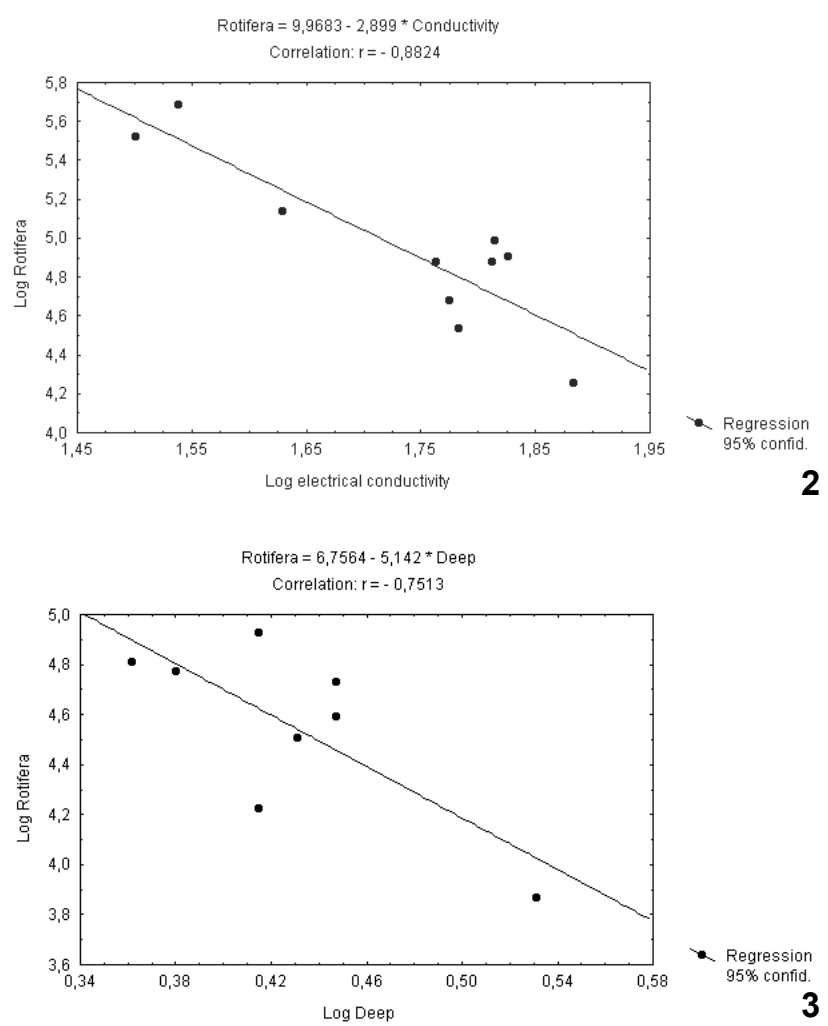

Figures 2-3. Correlation between: (2) electrical conductivity and Rotifera in low water; (3) between depth and Rotifera in high water.

species can live, either temporarily or permanently. Habitat selection is a process that operates at the level of the individual animal (Krebs 2001). The hydrologic complex that is the Amazon basin is formed by thousands of small rivers and probably has been, together with the exuberant forest, in dynamic equilibrium (SALATI et al. 1978). Mature (old) rivers that flow across plains and that have already reached their base level (limit below which erosion by flowing waters cannot occur) have a 
Table I. Environmental variables for Lago Amapá during the two main phases of the hydrologic cycle in 1997 and 1998 . (x) mean; (sd) standard deviation; (Dep) depth; (trans) transparency; (T) temperature; (Alkl) alkalinity; (Cond) electrical conductivity; (OD) dissolved oxygen; (L) water level; (-) loss of samples.

\begin{tabular}{|c|c|c|c|c|c|c|c|}
\hline \multirow{2}{*}{ Var Date } & Dep (m) & Trans (m) & $\mathrm{T}\left({ }^{\circ} \mathrm{C}\right)$ & $\mathrm{pH}$ & Cond $\left(\mu \mathrm{S} . \mathrm{cm}^{-1}\right)$ & OD (mg. $\left.\mathrm{L}^{-1}\right)$ & $\mathrm{L}(\mathrm{m})$ \\
\hline & $x \pm s d$ & $x \pm s d$ & $x \pm s d$ & $x \pm s d$ & $x \pm s d$ & $x \pm s d$ & $x \pm s d$ \\
\hline 08/V/1997 & $2.5 \pm 1.2$ & $0.26 \pm 0.28$ & $27.4 \pm 0.3$ & $6.7 \pm 0.2$ & $59.5 \pm 1.3$ & $3.5 \pm 1.4$ & 0 \\
\hline 15/V/1997 & $2.6 \pm 1.0$ & $0.15 \pm 0$ & $27.7 \pm 1.0$ & $7.0 \pm 0.0$ & $31.7 \pm 8.1$ & $4.8 \pm 0.0$ & $0.15 \pm 0$ \\
\hline 22/V/1997 & $2.5 \pm 1.1$ & $0.25 \pm 0$ & $30.3 \pm 1.4$ & $7.0 \pm 0.4$ & $42.7 \pm 7.2$ & $5.5 \pm 2.7$ & $0.20 \pm 0$ \\
\hline 29/V/1997 & $3.0 \pm 1.2$ & $0.28 \pm 0.28$ & - & $7.1 \pm 0.0$ & $60.7 \pm 8.2$ & $7.6 \pm 1.1$ & $0.40 \pm 0$ \\
\hline 05/VI/1997 & $2.7 \pm 1.1$ & $0.38 \pm 0.76$ & $31.2 \pm 0.9$ & $7.2 \pm 0.4$ & $67.2 \pm 3.3$ & $6.5 \pm 1.0$ & $0.40 \pm 0$ \\
\hline 12/VI/1997 & $3.1 \pm 1.7$ & $0.25 \pm 0$ & $25.9 \pm 0.3$ & $7.5 \pm 0.0$ & $34.5 \pm 25.8$ & $4.8 \pm 1.0$ & $0.40 \pm 0$ \\
\hline 19/VI/1997 & $2.3 \pm 1.1$ & $0.33 \pm 0.11$ & $27.7 \pm 0.7$ & $8.7 \pm 0.9$ & $64.9 \pm 2.2$ & $3.7 \pm 1.4$ & $0.50 \pm 0$ \\
\hline 26/VI/1997 & $2.6 \pm 1.1$ & $0.45 \pm 0.5$ & $28.9 \pm 0.7$ & $8.0 \pm 0.2$ & $57.9 \pm 15.8$ & $3.7 \pm 2.4$ & $1.00 \pm 0$ \\
\hline 02/VII/1997 & $2.3 \pm 1.0$ & $0.28 \pm 0.28$ & $25.8 \pm 0.7$ & $7.4 \pm 0.1$ & $76.6 \pm 3.2$ & $2.2 \pm 0.3$ & $0.90 \pm 0$ \\
\hline 30/X/1997 & $2.4 \pm 1.0$ & $0.35 \pm 0.50$ & $32.0 \pm 1.1$ & $8.2 \pm 1.0$ & $65.3 \pm 0.7$ & $5.5 \pm 1.7$ & $0.80 \pm 0$ \\
\hline 05/I/1998 & $2.7 \pm 1.0$ & $0.45 \pm 0.10$ & $29.8 \pm 0.3$ & $6.5 \pm 0.3$ & $67.4 \pm 0.1$ & $6.3 \pm 1.1$ & $0.55 \pm 0$ \\
\hline $12 / I / 1998$ & $2.3 \pm 1.0$ & $0.43 \pm 0.57$ & $31.5 \pm 0.5$ & $7.3 \pm 0.8$ & $60.6 \pm 2.2$ & $7.6 \pm 1.6$ & $0.40 \pm 0$ \\
\hline 19/I/1998 & $2.4 \pm 1.1$ & $0.33 \pm 0.11$ & $30.1 \pm 1.1$ & $6.3 \pm 0.7$ & $83.5 \pm 40.5$ & $5.2 \pm 1.8$ & $0.35 \pm 0$ \\
\hline 26/I/1998 & $2.8 \pm 1.1$ & $0.46 \pm 0.57$ & $29.3 \pm 1.5$ & $7.0 \pm 0.9$ & $45.2 \pm \quad 2.8$ & $4.9 \pm 0.7$ & $0.90 \pm 0$ \\
\hline 02/II/1998 & $2.8 \pm 1.0$ & $0.56 \pm 0.57$ & $31.0 \pm 1.7$ & $5.3 \pm 0.3$ & $44.1 \pm 3.4$ & $4.4 \pm 0.9$ & $0.39 \pm 0$ \\
\hline 09/II/1998 & $2.6 \pm 1.1$ & $0.53 \pm 0.76$ & $28.9 \pm 0.3$ & $4.8 \pm 0.1$ & $45.5 \pm 1.1$ & $3.3 \pm 0.7$ & $0.29 \pm 0$ \\
\hline $16112 / 1998$ & $2.6 \pm 1.1$ & $0.63 \pm 0.10$ & $30.0 \pm 0.6$ & $5.3 \pm 0.1$ & $45.1 \pm 2.8$ & $3.8 \pm 1.3$ & $0.24 \pm 0$ \\
\hline 26/II/1998 & $3.4 \pm 1.2$ & $0.43 \pm 0.11$ & $29.3 \pm 0.2$ & $5.4 \pm 0.5$ & $35.7 \pm 2.0$ & $3.1 \pm 0.1$ & $0.48 \pm 0$ \\
\hline
\end{tabular}

sinuous appearance. The snaking stretches of these rivers are called meanders. In general, a large number of lakes are found along side of meander rivers. These lakes are formed by the isolation of meanders through processes of erosion and sedimentation of the banks. The lakes thus formed are so-called horseshoe, or meander lakes and are probably the most common lakes in Brazil. They are also called oxbow lakes and are numerous in the Amazonian region, because this region has few elevations and a large number of meandering rivers, thereby offering conditions favoring the formation of inumerous horseshoe lakes. Also, components of the landscape surrounding a lake, stream or river can have a strong influence on water quality. Elements of the landscape may serve as sources, sinks, or transformers for nutrients. Moreover, biotic factors such as vegetation cover, which play a decisive role in the decomposition of organic litter, determine the types of running waters in Amazonia (Sioli 1984, Esteves 1998, TuRner 1998).

Lago Amapá is one of these environments, which receives water from the Rio Acre during some months of the year. In Lago Amapá, as the hydrographic level increased with the entrance of water from the Rio Acre, as of January 19, 1998, only a few rotifer species appeared, such as Brachionus calicyflorus anuraeformis, Lecane leontina, Lecane ludwigi. Despite the changes caused by the increase in hydrographic levels, these were modest in relation to ecosystems of other floodplains, possibly explained by the meander form of the lake in study. However, some studies of floodplains have attributed the increase in zooplanktonic diversity to an increase in the hydrographic levels (Hardy 1980, Koste \& Robertson 1983, Hardy et al. 1984, Corrales de Jacobo \& Frutos 1985, Bonecker et al. 1994, Bonecker \& LANSAC-TôHA 1994). Probably, lakes formed from meanders favor the deposit of large amounts of clay, derived from erosion and sedimentation along the banks of the lake. These lakes would differ from other existing lakes in the floodplain of the Amazonian Basin and the Paraná, influencing then the existing diversity in this environment. The erosion mechanisms, especially at the time of the full one, modify the $\mathrm{pH}$ of the water making it acid and hindering the development of certain species. Concomitantly, electrical conductivity was also altered, as a variable that correlates with $\mathrm{pH}$, which in the present study was found to be negatively correlated with abundance of rotifers.

Generally, rotifers showed a planktonic character, possibly due the almost total absence of aquatic macrophytes, which 
Table II. List of the species of rotifers and microcrustaceans registered for the three sampling stations (low water phase/1997 and high water phase/1998)*. Habitat according to Koste \& SHIEl (1991), KOSTE \& TOBIAS (1987), and others.

\begin{tabular}{|c|c|c|}
\hline Táxons & Habitat & New registers \\
\hline \multicolumn{3}{|l|}{ Asplanchnidae } \\
\hline Asplanchna brightwelli Gosse, 1850 & Planktonic & + \\
\hline Asplanchna sieboldi (Leydig, 1854) & Planktonic & + \\
\hline \multicolumn{3}{|l|}{ Brachionidae } \\
\hline Brachionus falcatus Zacharias, 1898 & Planktonic & \\
\hline Brachionus caudatus Barrois \& Daday, 1884 & Planktonic & \\
\hline Brachionus dolabratus Harring, 1915 & Planktonic & \\
\hline Brachionus calicyflorus anuraeformis (Brehm, 1903) & Planktonic & \\
\hline Brachionus calicyfloris Pallas, 1766 & Planktonic & + \\
\hline Brachionus havanaensis Rousselet & Planktonic & + \\
\hline Brachionus plicatilis (O.F. Müller, 1786) & Planktonic & + \\
\hline Keratella americana Carlin, 1943 & Planktonic & \\
\hline Keratella cochlearis cochlearis Plate, 1886 & Planktonic & \\
\hline Keratella cochlearis hispida Lauterborn, 1900 & Planktonic & + \\
\hline Platyionus patulus macrachanthus (Daday, 1905) & Planktonic & \\
\hline Platyias quadricornis (Ehrenberg) 1832 & Planktonic & \\
\hline \multicolumn{3}{|l|}{ Euchlanidae } \\
\hline Dipleuchlanis propatula macrodactyla (Hauer, 1965) & Littoral & \\
\hline Euchlanis dilatata Ehrenberg, 1832 & Planktonic & + \\
\hline \multicolumn{3}{|l|}{ Trichocercidae } \\
\hline Trichocerca bicristata Gosse, 1887 & Planktonic & \\
\hline Trichocerca chattoni De Beauchamp, 1907 & Planktonic & \\
\hline Trichocerca similis (Plate, 1886) & Planktonic & \\
\hline \multicolumn{3}{|l|}{ Lecanidae } \\
\hline Lecane curvicornis (Murray) 1913 & Littoral & + \\
\hline Lecane elsa (Hauer, 1931) & Littoral & + \\
\hline Lecane leontina (Tuner, 1892) & Littoral & \\
\hline Lecane bulla (Gosse, 1851) & Littoral & \\
\hline Lecane ludwigi (Eckstein, 1883) & Littoral & + \\
\hline \multicolumn{3}{|l|}{ Notommatidae } \\
\hline Cephalodella gibba (Ehrenberg, 1838) & Littoral & + \\
\hline Cephalodella hollowdayi Koste, 1986 & Littoral & + \\
\hline \multicolumn{3}{|l|}{ Colurellidae } \\
\hline Lepadella ovalis (O. F. Müller, 1786) & Littoral & + \\
\hline Lepadella patella (O. F. Müller, 1786) & Littoral & + \\
\hline \multicolumn{3}{|l|}{ Synchaetidae } \\
\hline Polyarthra vulgaris Carlin, 1943 & Planktonic & + \\
\hline \multicolumn{3}{|l|}{ Filinidae } \\
\hline Filinia terminalis (Ehrenberg) 1834 & Planktonic & + \\
\hline Filinia opoliensis (Zacharias), 1898 & Planktonic & \\
\hline Filinia pjeleri Hutchinson, 1964 & Planktonic & \\
\hline Filinia longiseta (Ehrenberg) 1834 & Planktonic & \\
\hline \multicolumn{3}{|l|}{ Epiphanidae } \\
\hline Epiphanes macrourus (Barrois \& Daday, 1894) & Planktonic & + \\
\hline Epiphanes pelagica (Jennings, 1900) & Planktonic & + \\
\hline \multicolumn{3}{|l|}{ Hexarthridae } \\
\hline Hexarthra intermedia braziliensis (Hauer, 1953) & Planktonic & \\
\hline \multicolumn{3}{|l|}{ Trochosphaeridae } \\
\hline Trochosphaera aequatorialis Semper, 1872 & Planktonic & \\
\hline \multicolumn{3}{|l|}{ Testudinellidae } \\
\hline Testudinella patina (Hermann) 1783 & Planktonic & \\
\hline
\end{tabular}

* Also were found genera of the families Asplanchnidae (1), Brachionidae (2), Euchlanidae (1), Lecanidae (1), Proalidae (1), Synchaetidae (1), Epiphanidae (1), Hexarthridae (1), and Testudinellidae (1). 
Table III. Density values (ind/m3) found in the low-water phase/1997 $(n=10)$ and water-high phase/1998 $(n=8)$ for the most common rotifers with $\mathrm{a}=0.05,95 \%$ confidence interval.

\begin{tabular}{lrrrrrrr}
\hline \multirow{2}{*}{ Species } & \multicolumn{3}{c}{ Low-water phase } & & \multicolumn{3}{c}{ High-water phase } \\
\cline { 2 - 3 } \cline { 6 - 8 } & Average & Standard deviation & Confidence interval & & Average & Standard deviation Confidence interval \\
\hline Asplanchna brightwelli & 1.481 & 4.057 & 2.514 & & 11.000 & 68.000 & 34.000 \\
Asplanchna sieboldi & 5.596 & 15.993 & 9.912 & & 13.000 & 49.000 & 47.000 \\
Brachionus calicyflorus anuraeformis & 462.000 & 1.341 & 831.000 & & 3.935 & 5.042 & 688.000 \\
Keratella cochlearis cochlearis & 52.981 & 115.441 & 71.549 & & 868.000 & 1.128 & 782.000 \\
Keratella cochlearis hispida & 879.000 & 3.411 & 2.114 & & 2.106 & 3.116 & 2.159 \\
Filinia terminalis & 277.000 & 1.521 & 942.000 & & 6.944 & 7.505 & 5.200 \\
Filinia opoliensis & 26.666 & 67.121 & 41.600 & & 7.754 & 14.879 & 10.268 \\
\hline
\end{tabular}

Table IV. Variance analysis and comparison of means for transformed values $(\log (x))$ of the rotifer and environmental variables in the low-water phase/1997 $(n=10)$ and water-high phase/1998 $(n=8)$, except temperature, respectively $n=9$ and $n=8$.

\begin{tabular}{|c|c|c|c|c|c|}
\hline Variables & C.V. & $\mathrm{F}$ & $\mathrm{P}$ & Means of Treatments & Standard deviation \\
\hline Rotifera & 8.2994 & $4.36 \mathrm{NS}$ & 0.0530 & $\begin{array}{l}11.3858 a \\
10.4824 a\end{array}$ & $\begin{array}{l}0.9838 \\
0.8093\end{array}$ \\
\hline Transparency & 7.2702 & $15.92^{\star *}$ & 0.0011 & $\begin{array}{l}1.4603 a \\
1.6605 b\end{array}$ & $\begin{array}{l}0.1303 \\
0.0858\end{array}$ \\
\hline Temperature & 1.7688 & $3.33 \mathrm{NS}$ & 0.0882 & $\begin{array}{l}3.3487 a \\
3.4016 a\end{array}$ & $\begin{array}{l}0.0772 \\
0.0283\end{array}$ \\
\hline $\mathrm{pH}$ & 11.2352 & $16.88^{* *}$ & 0.0008 & $\begin{array}{l}7.4800 a \\
5.9875 b\end{array}$ & $\begin{array}{l}0.6303 \\
0.9109\end{array}$ \\
\hline Dissolved Oxygen & 22.2223 & $0.02 \mathrm{NS}$ & 0.8992 & $\begin{array}{l}1.5104 a \\
1.5310 a\end{array}$ & $\begin{array}{l}0,3574 \\
0.3103\end{array}$ \\
\hline Electrical conductivity & 7.3139 & $0.12 \mathrm{NS}$ & 0.7339 & $\begin{array}{l}3.9900 \mathrm{a} \\
3.9423 \mathrm{a}\end{array}$ & $\begin{array}{l}0.2995 \\
0.2779\end{array}$ \\
\hline Depth & 11.2725 & $0.49 \mathrm{NS}$ & 0.4945 & $\begin{array}{l}0.9508 a \\
0.9869 a\end{array}$ & $\begin{array}{l}0.1011 \\
0.1182\end{array}$ \\
\hline
\end{tabular}

$\left({ }^{\star}\right) \mathrm{p}(0.01,($ N.S.) no significant. Average values followed by different letters in the same row are different by Tukey test.

function as a niche for shore-inhabiting species. The process of soil erosion along the banks made it difficult for the establishment of littoral species. However the shore-inhabiting Lecanideae family had the the largest number of representatives. The family most frequently observed in our study was Brachionidae, followed by the Lecanidae family which is predominant in typically tropical environments. These families had also been found to be dominant in the studies of CARVALHO (1983). Similarly, they were found to be abundant in aquatic environments of the Amazônia.

In relation to the composition of the zooplanktonic community, the number of taxons (48) found in Lago Amapá can be related to the diversification of niches present in each phase of the hydrologic cycle, and to the absence of aquatic plants. This number is low compared to the diversity reported for other basins and other floodplain lakes. RoBERTSON \& HARDy (1984), reporting on Amazonian data, estimated 250 species of roti- fers. According to Roche et al. (1994) the Amazonian basin has a greater diversity of zooplankton (Rotifera + Cladocera + Copepoda), with 268 Rotifera, than do the basins of the Paraguai, Paraná and São Francisco. The high number of taxons registered for the rotifers (48), compares with the date of Sendacz \& Melo-Costa (1991), who described the presence of Cladocera and Copepoda also in this lake and Lago Novo Andirá, in relation to the other groups of zooplankton in the neotropical region. This is also in line with that observed by various authors who have studied the floodplains of Amazonia (Hardy 1980, Koste \& RoberTson 1983, Hardy et al. 1984, Bozelli 1992, Koste \& RoberTson 1998) and other floodplains (Jose DE Paggi 1981, Corrales de Jacobo \& Frutos 1985). Still in accordance with this last author, the high number of taxons registered for rotifers in floodplains is supported by, among other factors, the heterogeneity of environments present. Therefore, this lake was not favorable due to this factor, accounting for 
the low number of taxons present. The larger abundance of rotifers during the low-water period demonstrated that the fluctuation in water level had influenced this group more. This factor also was observed by HaRdy (1980) and LANSAC-TôHa et al. (1993), possibly due to increased food availability. Therefore, dilution caused by high water affects food availability. According to Kitchell (1998), food is a prime factor for non-photosynthetic organisms.

There was a low degree of rotifer diversity in the environment studied. The presence and success of an organism or group of organisms depend on a combination of conditions. Any condition that approximates or exceeds the limits of tolerance is said to be a limiting condition or limiting factor. Combining the idea of the minimum and the concept of the tolerance limits it is arrived the most general and useful concept of the limiting factors. Thus, organisms are controled in nature by (1) the quantity and variability of materials for which there are minimum requirements, and also critical physical factors, and (2) the tolerance limits of the organisms themselves to these and other components of the environment. Of the total number of species in a trophic component, or in a community taken as a whole, a relatively small percentage is as a rule abundant (represented by large numbers of individuals, a large biomass or productivity, or any other indication of impact, and a large percentage are rare (with small impact values). While only a few common and dominant species contribute largely to the energy flow in each trophic group, it is the large number of rare species that determines essentially species diversity at trophic levels of communities taken as a whole. The ratios between the number of species and the impact values (numbers, biomass, productivity, and so forth) for the individuals are designated by species diversity indices. The diversity of species tends to be small in ecosystems controled physically (that is, subjected to strong, physical and chemical limiting factors) and high in ecosystems controled biologically. Communities in stable environments, such as tropical rainforests, have a greater species diversity than communities subjected to perturbations or cycles by human or naturals causes. Tropical waters of little depth is one factor that diminishes diversity in a habitat (ODum 2001). The lake studied had a maximum depth of $3.4 \mathrm{~m}$, contributing one more factor limiting diversity. In addition to data on diversity, the present study also demonstrated that the abundance of rotifers correlated negatively with depth.

A significant difference between the means was observed only using the F test, when examining the seasonality for transparency and $\mathrm{pH}$. The results for temperature, electric conductivity and dissolved oxygen versus the presence of Rotifera demonstrated a low degree of seasonal variation in this study in contrast to that reported by CAMARGo \& Esteves (1995). These authors found that in the oxbow lake of Rio Mogi-Guaçu in São Paulo, a high degree of seasonal variation in the results for these parameters as a result of the pulse of flooding. However,
ScнміDт (1973) also did not observe great seasonal variations, when studying such parameters in Lago Castanho in Central Amazonia. Temperature remained practically constant during the entire period of the hydrologic cycle, according to Sioli (1984), water temperature, running in an equatorial lowland where temperature fluctuations are minimal, the waters of the Amazon have a surprisingly constant temperature, and constitute the most thermally stable waters on earth. ThомAz et al. (1997) also observed a constant water temperature in the floodplain of the Rio Paraná, which was characterized by small secular oscillations, except for the occurrence of a small increase in the high-water phase. Some taxons appeared in Lago Amapá at basic or neutral $\mathrm{pH}$ and relatively low dissolved oxygen levels, such as Platyas quadricornis, Lepadella ovalis, Trichocerca similis and Testudinella patina. Therefore, these factors are not considered limiting for these species in the lake studied. However, according to Kiтchell (1998), just as oxygen concentration often is an important constraint for aquatic organisms, especially animails.

Lago Amapá is also being subjected to human activiy resulting from pollution. Human changes in land use have greatly increased the amounts of nutrients and silt that enter lakes. Most increases in nutrient flow can be linked to urban run-off through storm water systems, effluent from sewage treatment plants, failing septic systems, agricultural run-off, deforestation, and nutrient-rich waste waters from industries such as food processing. The distribution of many species can be affected by human-mediated changes in habitats. Human changes to landscapes and environments may make some habitat selection maladaptative (Perry \& Vanderklein 1996, Krebs 2001), interfering with the diversity of species.

Asplanchna was an abundant genus in Lago Amapá. According to Margalef (1983), it is a predador organism, ingesting large and mobile algae, as well as other smaller zooplanktonic organisms. The degree of predation affects greatly the diversity of populations or of prey. A moderate predation often reduces the density of dominant species, thereby providing less competitive species increased opportunities to utilize space and resources. The presence of predators may limit the geographic distribution of many species. Predator limitations on prey distribution often operate on a local scale. Prey rarely limit the distribution of their predators (Odum 2001, KREBS 2001). The establishment of these organisms in the lake studied was propitious, since the algae present in Lago Amapá were mostly large ( $>15 \mu \mathrm{m}$ ), in addition to being abundant, and of the filamentous type, for example the blue-green algae cyanophyceae (Keppeler et al. 1999a,b; Keppeler \& Hardy 2002). Chlorophyceae are common in Lago Amapá (Keppeler et al. 1999b), which favor the presence of species of the genus Brachionus, abundant in Lago Amapá. Hu et al. (2002), who studied the rotifer Brachionus angularis, observed that there were very significant effects of food concentrations on population growth rate, body size and egg size in this species when Chlorella pyrenoi-

Revista Brasileira de Zoologia 21 (2): 233-241, junho 2004 
dosa was used as food. A study by Lucia-PAvon et al. (2001) also showed that different densities of live and dead Chlorella vulgaris affected the population growth of the rotifers Brachionus calyciflorus and Brachionus patulus (Platyonus patulus).

The communities in rigorous environments should vary in diversity in accordance with their relative abundance component, while diversity in non rigorous environments (biologically controled) should depend on the number of species.

\section{ACKNOWLEDGMENTS}

We are grateful to Dr. Cláudia Costa Bonecker, Suzana Sendacz, and Pedro González Dominguez for their valuable critique of this study and part of the Masters dissertation in Ecology and Management of Natural Resources. Universidade Federal do Acre. We also thank Willians Monteiro Ayache (technician, Department of Natural Sciences) for his help with samplings at Lago Amapá.

\section{REFERENCES}

Apha (American Public Health Association). 1992. Standard Methods for Examination of Water and Wastewater. Springfield, Bru-El Graphic Inc., $18^{\text {th }}$ ed., 1155 p.

Amoros, C. 2001. The concept of habitat diversity between and within ecosystems applied to river side-arm restoration. Environmental Management, New York, 28 (6): 805-17.

Bonecker, C.C.; F.A. LANSAC-TôHa \& A. Staub. 1994. Qualitative study of rotifers in different environments of the high Paraná river floodplain (MS) - Brasil. Revista Unimar, Maringá, 16 (Supl. 3): 1-16.

BONeCKer, C.C.; S.L. Bonecker; R.L. Bozelli; F.A. Lansac-TôHa \& L. F.M. Velho. 1996. Zooplankton composition under the influence of liquid wastes from a pulp mill in middle doce river (Belo Horizonte, MG, Brazil). Arquivos de Biologia e Tecnologia, Curitiba, 39 (4): 893-901.

Bonecker, C.C. \& F.A. LANSAC-TöHa. 1996. Community structure of rotifers in two environments of the upper River Parana floodplain (MS) - Brazil. Hydrobiologia, Dordrecht, 325: 137-150.

BozelLI, R.L. 1992. Composition of the zooplankton community of Batata and Mussurá lakes and of the Trombetas River, State of Pará, Brazil. Amazoniana, Plön, 12 (2): 239-261.

-1994. Zooplankton community density in relation to water level flutuation and inorganic turbity in an Amazonian lake, "Lago Batata" State of Pará Brazil. Amazoniana, Plön, 13 (1-2): 17-32.

Camargo, A.F.M. \& F.A Esteves. 1995. Influence of water level variation on fertilazation of na oxbow lake of Rio MogiGuaçu, State of São Paulo, Brazil. Hydrobiologia, Dordrecht, 299: 185-193.

Carvalho, M.L. 1983. Efeitos da flutuação do nível da água sobre a densidade e composição do zooplâncton em um lago de várzea da Amazônia, Brasil. Acta Amazonica, Manaus,
13 (5-6): 715-724.

Corrales de JaCobo, M.A. \& S.M. Frutos. 1985. Estudio preliminar del zooplancton de la laguna Sirena (Corrientes, Argentina). Physis, Secc. B, Buenos Aires, 43 (104): 43-48.

Esteves, F.A. 1998. Fundamentos de Limnologia. Rio de Janeiro, Editora Interciência, 2a ed., 602p.

Golterman, H.L.; R.S. Clymo \& M.AM. OhmStad. 1969. Methods for Chemical Analysis of Fresh waters - IBP. Oxford, Blackwell Scientific Publications, XVI+217p.

. 1978. Methods for physical and chemical analysis of Fresh waters. Oxford, Blackwell Scientific Publications, IBP Handbooks 8, $2^{\text {nd }}$ ed., 213p.

GreEN. J. 1972. Freshwater ecology in the Mato Grosso, Central Brazil. III. Associations of Rotifera in meander lakes of the rio Suiá Missú. Journal of Natural History, Oxon, 6: 229241.

HARDY, E.R. 1980. Composição do zooplâncton em cinco lagos da Amazônia Central. Acta Amazonica, Manaus, 10: 557609.

HaRdy, E.R.; B.A. Robertson \& W. Koste. 1984. About relationship between the zooplankton and fluctuating water levels of Lago Camaleão, a Central Amazonian várzea lake, Amazoniana, Plön, 9: 43-52.

Hu H.; Y. XI \& H. GeNG. 2002. Effects of food concentration on population growth, body size, and egg size of the freshwater rotifer Brachionus angularis. Ying Yong Sheng Tai Xue Bao 13 (7): 875-878.

José DE PAGgI, S. 1981. Variaciones temporales y distribución horizontal del zooplancton en algunos cauces secundarios del rio Paraná Medio. Studies on Neotropical Fauna and Environment, Lisse, 16: 185-199.

Junk, W.J.; P.B. Bayley \& R.E. Sparks. 1989. The flood pulse concept in river-floodplain systems, p. 110-127. In: D.P. Dodge (Ed.). Proceedings of the International Large River Symposium. Canadian Special Publication of Fisheries and Aquatic Sciences.

Keppeler, E.C. \& E.R. Hardy. 2002. Estimativa da média de maturidade das fëmeas com ovos de Moina minuta no Lago Amapá em Rio Branco, Estado do Acre. Acta Scientiarum, Maringá, 24 (4): 321-328.

Keppeler, E.C. \& E.R. Hardy. 2004. Vertical distribution of zooplankton in the water column of Lago Amapá, Rio Branco, Acre, Brazil. Revista Brasileira de Zoologia, Curitiba, 21 (2): 169-177.

Keppeler, E.C.; M.R. Marques-Lopes \& C.S. Lima. 1999a. Ficoflórula do Lago Amapá em Rio Branco-Acre, I: Euglenophyceae. Revista Brasileira de Biologia, São Carlos, 59 (4): 679-686.

— 1999b. Ficoflórula do Lago Amapá em Rio BrancoAcre, II: Chlorophyta. Revista Brasileira de Biologia, São Carlos, 59 (4): 687-691.

Kitchell, J.E. 1998. Physiological Ecology Tradeoffs for Individuals, p. 164-198. In: S. I. Dodson; F.H. Allen; S.R. Carpenter; A.R. Ives; R.L. Jeanne; J.F. Kitchell; N.E. Langston

Revista Brasileira de Zoologia 21 (2): 233-241, junho 2004 
\& M.G. TURNER (Eds). Ecology. Oxford, University Press, 434p.

Koste, W. \& B. Roberston. 1983. Taxonomic studies of the Rotifera (Phylum Aschelminhthes, from a Central Amazonian várzea lake, Lago Camaleão (Ilha da Marchantaria, rio Solimões, Amazonas. Amazoniana, Plön, 8: 225-254.

1998. The Rotifera of shallow waters of the Ilha de Maracá, p. 399-401. In: W. Milliken \& J.A RatTer (Eds). The Biodiversity and Environment of na Amazonian Rainforest. London, John Wiley \& Sons, 528p.

Koste, W. \& R.J. Shiel. 1991. Rotifera from Australian Inland waters, VII. Notommatidade (Rotifera: Monogononta). Transactions of the Royal Society of South Australia, Adelaide, 115 (3): 111-159.

Koste, V.W. \& W. Tobias. 1987. Zur Rädertierfauna des SankaraniStausees im Einzugsgebiet des Niger, Republik Mali, Westafrika (Aschelminthes: Rotatoria). Archiv fur Hydrobiologie, Plön, 108 (4): 499-515.

KREBS, C.J. 2001. Ecology: The experimental analysis of distribution and abundance. San Francisco, Benjamin Cummings, $5^{\text {th }}$ ed., 695p.

Lansac-TôHa, F.; A F. Lima; S.M. Thomaz \& M.C. Roberto. 1992. Zooplâncton de uma planície de inundação do rio Paraná. I. Análise qualitativa e estrutura da comunidade. Revista Unimar, Maringá, 14 (Suppl.): 35-55.

Lansac-TôHa, F.; A.F. Lima; S.M. Thomaz \& M.C. Roberto. 1993. Zooplâncton de uma planície de inundação do rio Paraná. II. Variação sazonal e influência dos níveis fluviométricos sobre a comunidade. Acta Limnologica Brasiliensia, São Paulo, 6: 42-55.

Lucia-Pavon, E; S.S. SARMa \& S. NANDini. 2001. Effect of different densities of live and dead Chlorella vulgaris on the population growth of rotifers Brachionus calyciflorus and Brachionus patulus (Rotifera). Revista de Biologia Tropical, Costa Rica, 49 (3-4): 895-902

Margalef, R. 1983. Limnología. Barcelona, Ed. Ômega, 1009p.

Odum, E.P. 2001. Fundamentos de ecologia. Lisboa, Fundação Calouste Gulbenkian, 927p.

Perry, J. \& E. VAnderklein. 1996. Water quality management of a natural resource. Blackwell Science, Cambridge, MA.

RoberTson, B.A. \& E.R. Hardy. 1984. Zooplankton of Amazonian lakes and rivers, p. 337-352. In: H. Sioli (Ed.). The Amazon. Limnology and landscape. Ecology of a mighty tropical river and its basin. Dr. The Hague, W. Junk Publishers, 763p.

Rocha, O.; T.M. TundisI \& J.G. TundisI. 1994. Latitudinal trends of zooplankton diversity in the Neotropical Region: Present knowledge and future needs. Anais da Academia Brasilei- ra de Ciências, Rio de Janeiro, 1 (66): 41-45.

Salati, E.; J. Marques \& L.C.B. Molion. 1978. Origem e distribuição das chuvas na Amazônia. Interciência, Caracas, 3: 200206.

Santos-Silva, E.N. dos; B.A. Robertson; J.L. W. Reid \& E.R. Hardy. 1989. Atlas de copépodos planctônicos, Calanoida e Cyclopoida (Crustacea), da Amazônia Brasileira. I. Represa de Curuá-Una, Pará. Revista Brasileira de Zoologia, Curitiba, 6 (4): 725-758.

SAS. 1998. Statistical analyses system. Cary, SAS Institute, vol. 5, 633p.

Schmidt, G.W. 1973. Studies on the primary production phytoplankton in the three types of amazonian waters, 3 : Primary productivity of phytoplankton in tropical floodplain lake of Central Amazonia, Lago do Castanho, Amazonas, Brasil. Amazoniana, Plön, 4 (4): 379-404.

SeNDACZ, S. \& S.S. MELo-Costa. 1991. Caracterização do Zooplâncton do Rio Acre e Lagos Lua Nova, Novo Andirá e Amapá (Amazônia, Brasil). Revista Brasileira de Biologia, São Carlos, 51: 463-470.

Sioli, H. 1968. Principal Biotopes of Primary Production in the Water of Amazonia, p. 591-600. In: R. Misra \& B. Gopal. (Eds). Proceeding Symposium Recent Advances Tropical Ecology. Varanasi, The International Society for Tropical Ecology.

- 1984. The Amazon and its main affluents: Hydrography, morphology of the river courses, and river types, $\mathrm{p}$. 127-165. In: H. Sioli (Ed.). The Amazon: Limnology and landscape ecology of a mighty tropical river and its basin, Monographiae biologicae. Dordrecht, W. Junk Publishers, 763p.

Thomaz, S.M.; M.C. Roberto \& L.M. Bini. 1997. Fatores limnológicos abióticos e clorofila- $a$ do pulso de inundação. In: A.E.A.M. Vazzoler; A.A. Agostinho \& N.S. Hahn (Eds). A planície de inundação do alto rio Paraná: aspectos físicos, químicos, biológicos e sócio econômicos. Maringá, Editora Universidade Estadual de Maringá, 73p.

Turner, M.G. 1998. Landscape Ecology Living in a Mosaic, p. 77-114. In: S.I. Dodson; F.H.A. Timothy; S.R. Carpenter; A.R. Ives; R.L. Jeanne; J.F. Kitchell; N.E. Langston \& M.G. Turner (Eds). Ecology. Oxford, University Press, 434p.

Waichman, A.; C.C. Garcia, E.R. Hardy; B.A Robertson. 2002. Composição do Zooplancton em diferentes ambientes do Lago Camaleão, na Ilha da Marchantaria, Amazonas, Brasil. Acta Amazonica, Manaus, 32 (2): 339-347.

Wetzel, RG. \& G.E. Likens. 1991. Limnological analyses. New York, Springer, 391p.

Received in 14.X.2003; accepted in 15.III.2004. 